\title{
Seasonal Variation of Phytoplankton Community in Navigable Channel of Gopalpur Port, East Coast of India: A Taxonomic Study
}

\author{
S. K. Baliarsingh, Biraja Ku. Sahu, S. Srichandan, K. C. Sahu* \\ Dept. of Marine Sciences, Berhampur University, Berhampur, 760007, Odisha, India
}

\begin{abstract}
The aim of this paper is to determine the current biological state of phytoplankton in the pelagic zone of Gopalpur Port navigable channel. The plankton samples were collected from a fixed sampling location in two different tides i.e. high tide and low tide during three different seasons i.e. pre-monsoon, monsoon, and post-monsoon of the year 2010. Ninety four species of phytoplankton were observed, of which diatom constituted 71 species, dinoflagellate 11 species, green algae 8 species and blue green algae (cyanobacteria) 4 species. Comparing the population of all the groups, the contribution of each group of phytoplankton was in the order of diatoms $>$ dinoflagellates $>$ blue green alga $>$ green alga in all the seasons. The population density of phytoplankton ranged from 2360 Nos./L to 53240 Nos./L (avg. 29683 Nos./L). In premonsoon and post monsoon, Asterionellopsis glacialis, an important bloom forming member of diatom group dominated the phytoplankton population. Among these ninety four species, Asterionellopsis glacialis, Thalassiothrix longissima, Chaetoceros curvisetus, Coscinodiscus gigas, Ditylum brightwellii were recorded in all the seasons and the other species have shown seasonal variation. The toxic phytoplankton such as Pseudonitzschia pungens, Dinophysis caudata were also recorded during our observation. Our study is a first attempt made in this environmentally sensitive region, being sensitive due to coastal erosion, port activities and adjacent mass nesting beach for Olive Ridley sea turtles.
\end{abstract}

Keywords Gopalpur Port, Phytoplankton, Seasonal Change, Taxonomy

\section{Introduction}

Phytoplankton are the main primary producers of marine and freshwater ecosystems. They play specific roles in biogeochemical cycling in marine ecosystems. Their roles in calcification, silicification, dimethyl sulphide (DMS) production and nitrogen fixing have been well established. These tiny organisms initiate the marine food chain by the process of photosynthesis and serve as primary food in marine pelagic zone[1]. Phytoplankton, as the basis of the trophic chain, forms the biological community which regulates the food chain for which scientific attention is focused when a management plan is needed or an evaluation of the ecosystem health is required[2-4]. Knowledge on taxonomy of phytoplankton is essential to study the community dynamics in spatio-temporal scale and to characterize it into functional groups[5]. The species composition and population density of phytoplankton are sensitive to environmental changes. Their documentation in relation to dynamic environment is a valuable

* Corresponding author:

kalicsahu@gmail.com (K. C. Sahu)

Published online at http://journal.sapub.org/ijmb

Copyright (C) 2012 Scientific \& Academic Publishing. All Rights Reserved characteristic of water quality. Coastal and near-shore waters are more productive regions in the marine environment due to nutrient add by means of regeneration, upwelling and land run-off. Phytoplankton blooms in these waters follow a seasonal pattern that shapes the coastal marine ecosystem. Environmental forcing, nutrient availability, predator communities and land-driven inputs are the major factors that control coastal and near-shore phytoplankton community and blooms[6]. Several anthropogenic factors in these environments can result in alteration of coastal water quality (eutrophication), introduction of non-native species (ballast action), alteration of predator community (overfishing), etc. As a result, non-periodic and exceptional blooms of both non-toxic or toxic phytoplankton species lasting for few weeks to months are frequently reported, influencing the seasonal patterns of dominant phytoplankton community structure, thereby affecting coastal and estuarine biogeochemical processes[7].

In harbour/port areas, the water quality is changing rapidly due to multiple human activities. The phytoplankton due to its importance in food web requires frequent study under such changing of environment. Regular cargo handling, fishing trawler movements and shipping intensification, anthropogenic pollutant influx are the key sources of water 
quality alteration that led the scientific community for regular monitoring.

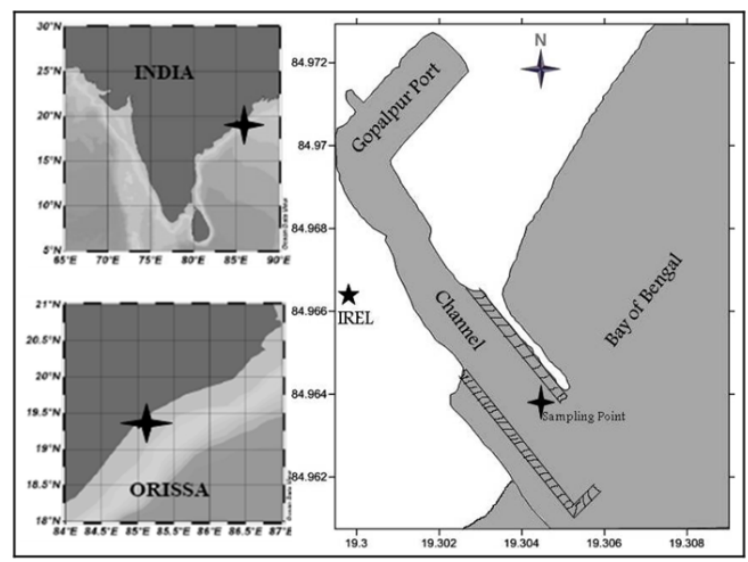

Figure 1. Sampling point in study area marks by asterix

We focus this study as a first attempt in this region to explore the phytoplankton composition in simultaneous seasonal and tidal basis. The outcome of this study will certainly useful for the coastal planners for environmental monitoring and impact assessment work.

\section{Materials and Methods}

The present research work was carried out on a fixed sampling point $\left(19^{0} 18^{\prime} 4.08^{\prime \prime} \mathrm{N}, 84^{\circ} 58^{\prime} 0.64^{\prime \prime} \mathrm{E}\right)$ in the navigable channel of Gopalpur Port, a seasonal port of Odisha, East Coast of India. This area (Figure.1) is sensitive due to port activities, and adjacent mass nesting beach for olive Ridley sea turtles. Rainfall of this region is primarily concentrated in Monsoon (South-West), which is the major climatic factor of this region. Though Gopalpur Port is a seasonal port, regular fishing trawler and boat movements are common. The navigational channel selected for this study was due to apprehending future pollution as a result of Petroleum Hydro-Carbon (PHC), oil spills and anthropogen ic load of organic and inorganic nutrients.

Sampling was carried out during three seasons i.e. pre-monsoon (PRM), monsoon (MON) and post-monsoon (POM) of year 2010 from a fixed location during high tide and low tide to determine the temporal and tidal variation in phytoplankton composition. Phytoplankton samples were collected from surface and stored in polythene bottles after preservation with Lugol's iodine solution. After concentrati ng the sample by sedimentation method, $1 \mathrm{ml}$ of sample was taken and examined with a Sedgwick rafter counting chamb er under a compound microscope (Nikon Eclipse-E600) with different magnifications. For taxonomical analysis, standard literatures[8-10] were referred.

\section{Results and Discussion}

A total of 94 phytoplankton species under four different groups were observed during the study, of which diatoms constituted 71 species, dinoflagellates 11 species, green alga
8 species and blue green alga (cyanobacteria) 4 species. Population wise Diatoms evolved as the major phytoplankton group followed by dinoflagellate, green algae and cyanobacteria. The dominance of diatoms followed by dinoflagellates is well reported in coastal waters[11].

In pre-monsoon (PRM) during low tide (LT) among diatoms Asterionellopsis glacialis (83.5\% of total phytoplan kton population) was the dominant species followed by Coscinodiscus eccentricus (4.2\%), Coscinodiscus sp. (1.6\%), Eucampia sp. (1.6\%) etc. Only 3 species of dinoflagellates, namely Ceratium furca $(0.2 \%)$, Prorocentrum micans $(0.1 \%)$ and Pyrophacus steinii $(0.1 \%)$ were found. We observed one species of green algae: Pediastrum duplex (3.0\%) (Table-3).

Table 1. Density (Nos./L) of different phytoplankton groups in Pre-monsoon, Monsoon and Post-monsoon

\begin{tabular}{ccccccc}
\hline & \multicolumn{2}{c}{ Premonsoon } & \multicolumn{2}{c}{ Monsoon } & \multicolumn{2}{c}{ Post monsoon } \\
\hline Groups & LT & HT & LT & HT & LT & HT \\
\cline { 2 - 7 } Diatom & 39000 & 48400 & 2099 & 11040 & 20380 & 53200 \\
\cline { 2 - 7 } \begin{tabular}{c} 
Dinoflagellate \\
Green algae \\
\cline { 2 - 7 } $\begin{array}{c}\text { Blue green } \\
\text { algae }\end{array}$
\end{tabular} & 160 & 1000 & - & 600 & 320 & 40 \\
\cline { 2 - 7 } Total & $\mathbf{4 0 3 6 0}$ & $\mathbf{4 9 8 0 0}$ & $\mathbf{2 3 6 0}$ & $\mathbf{1 1 6 4 0}$ & $\mathbf{2 0 7 0 0}$ & $\mathbf{5 3 2 4 0}$ \\
\hline
\end{tabular}

- :Absent, LT: Low Tide, HT: High Tide

Table 2. Number of species (Nos.) of different phytoplankton groups in Pre-monsoon, Monsoon and Post-monsoon

\begin{tabular}{lcccccc}
\hline \multirow{2}{*}{ Groups } & \multicolumn{2}{c}{ Pre-monsoon } & \multicolumn{2}{c}{ Monsoon } & \multicolumn{2}{c}{ Post-monsoon } \\
\cline { 2 - 7 } & LT & HT & LT & HT & LT & HT \\
\hline Diatom & 18 & 26 & 9 & 24 & 21 & 14 \\
\hline Dinoflagellate & 3 & 3 & - & 3 & 4 & 1 \\
\hline Green algae & 1 & - & 7 & - & - & - \\
\hline $\begin{array}{l}\text { Blue green } \\
\text { algae }\end{array}$ & - & 1 & 3 & - & - & - \\
\hline \multicolumn{1}{c}{ Total } & $\mathbf{2 2}$ & $\mathbf{3 0}$ & $\mathbf{1 9}$ & $\mathbf{2 7}$ & $\mathbf{2 5}$ & $\mathbf{1 5}$ \\
\hline
\end{tabular}

LT: Low Tide, HT: High Tide

In pre-monsoon (PRM) during high tide (HT), among diatoms Skeletonema costatum (13.3\%) was the dominant species followed by Chaetoceros constrictus (12.4\%), Chaetoceros lorenzianus (7.6\%), Chaetoceros sp. (7.2\%), Eucampia zoodiacus (5.2\%). Three dinoflagellate speciesProrocentrum micans (0.8\%), Protoperidinium sp. (0.8\%) and Dinophysis caudate $(0.4 \%)$ were observed. One species of cyanobacteria Oscillatoria sp. $(0.8 \%)$ was observed (Table-3).

In monsoon (MON) during low tide (LT) among diatoms Thalassiothrix longissima (34.5\%) was the dominant species followed by Coscinodiscus gigas (21.6\%), Surirella $s p$. (12.0\%), Synedra sp. (12.5\%). No dinoflagellate species was observed. Highest number of green algae species was observed during this sampling period (Table-2 \& 3). The dominant green algae species were Staurastrum sp. (2.8\%), 
Eudorina elegans (2.3\%), Botryococcus sp. (1.4\%). Among cyanobacteria Phromidium sp. $(0.9 \%)$ was the dominant species followed by Anabaena sp. (0.5\%) and Spirulina sp. $(0.5 \%)$ (Table-3). In monsoon (LT), higher number of green alga and cyanobacteria were observed. The occurrence of freshwater cyanobacteria species - Anabaena sp. and Spirulina sp. indicates influx of freshwater from inner port area to the channel during low tide due to monsoonal rain.

In monsoon (MON) during high tide (HT) the diatom Thalassiothrix longissima (17.9\%) was dominant followed by Chaetoceros sp. (16.5\%), Coscinodiscus gigas (12.4\%), Ditylum brightwellii (11.0\%) (Table-3). Dominance of Thalassiothrix longissima was previously reported by Paul et al., 2007[12] in central Bay of Bengal. The 3 species of dinoflagellates observed were Prorocentrum maxima (2.7\%), Prorocentrum micans (1.4\%) and Peridinium sp. (1.0\%). No species of green algae and cyanobacteria were observed.

In post-monsoon (POM) during low tide (LT) among diatoms Asterionellopsis glacialis (80.0\%) was the dominant species followed by Coscinodiscus eccentricus (5.6\%), Coscinodiscus sp. (1.9\%), Biddulphia mobiliensis (1.7\%). Among dinoflagellates, Ceratium tripos (0.6\%) was the dominant species followed by Ceratium trichoceros $(0.4 \%)$, Prorocentrum gracile $(0.4 \%)$. No species of green algae and cyanobacteria were observed (Table-3).

In post-monsoon (POM) during high tide (HT) the same diatom Asterionellopsis glacialis $(95.9 \%)$ was dominant followed by Coscinodiscus eccentricus (1.4\%), Biddulphia sp. $\quad(0.8 \%)$, Thalassiothrix frauenfeldii $(0.5 \%)$. One dinoflagellate species Dinophysis caudate $(0.1 \%)$ was observed (Table-3). No species of green algae and cyanobacteria were observed.
In pre-monsoon[HT (83.5\%)] and post-monsoon[HT $(95.9 \%) \&$ LT (80.0\%)], Asterionellopsis glacialis an important bloom forming member of diatom group, dominated the phytoplankton population with more than $80 \%$ composition. Previously predominance of bloom forming Asterionellopsis glacialis (Figure.2) was reported in estuarine waters of Rushikulya River[13] and coastal waters of Gopalpur[14] close to the study area.

Pollution indicating species from cyanobacterial group viz. Oscillatoria sp. (Figure.2), Anabaena sp. were recorded during high tide (HT) of pre-monsoon and low tide (LT) of monsoon season respectively[15].

As far as seasonal abundance of phytoplankton isconcern ed, the trend pre-monsoon (45080 Nos./L) > post-monsoon (36970 Nos./L) > monsoon (7000 Nos./L) was observed (Table-1). Highest abundance of phytoplankton during pre-monsoon season might be due to the dominance of diatoms and the lowest during monsoon might be due to the stratification of water column to a large extent because of heavy rainfall, high turbidity caused by river run-off/land run-off, reduced salinity, decreased temperature and $\mathrm{pH}$, overcast sky and cool conditions[16]. Species composition varied considerably in the three seasons. This might be attributed to change in environmental variables specially nutrients and temperature in different seasons[17][18].

As far as temporal species number is concerned more number of species (tidal mean) were identified during pre-monsoon (26) followed by monsoon (23) and post-monsoon (20) (Table-2). Tidal examination of phytoplankton samples for qualitative purpose revealed that more number of species were abundant during high tide than low tide with an exception in post monsoon.

Table 3. Phytoplankton species list, abundance (Nos./L) and percentage composition (in bracket) in Pre-monsoon, Monsoon and Post-monsoon

\begin{tabular}{|c|c|c|c|c|c|c|}
\hline & \multicolumn{2}{|c|}{ Pre-monsoon } & \multicolumn{2}{|c|}{ Monsoon } & \multicolumn{2}{|c|}{ Post-monsoon } \\
\hline & $\mathrm{LT}$ & HT & $\mathrm{LT}$ & HT & $\mathrm{LT}$ & HT \\
\hline DIATOM & & & & & & \\
\hline Actinotychus undulatus & - & - & - & - & $40(0.2)$ & - \\
\hline Amphiprora gigantea & - & - & - & - & $40(0.2)$ & $80(0.2)$ \\
\hline Amphiprora gigantea & $40(0.1)$ & - & - & - & - & - \\
\hline Amphiprora sp. & $80(0.2)$ & - & - & - & - & - \\
\hline Amphora lineolata & - & - & - & - & $40(0.2)$ & - \\
\hline Asterionellopsis $\mathrm{sp}$. & $440(1.1)$ & - & - & - & - & - \\
\hline Asterionellopsis glacialis & $33720(83.5)$ & - & - & $160(1.4)$ & $16560(80.0)$ & $51040(95.9)$ \\
\hline Bacteriastrum comosom & - & - & - & $120(1.0)$ & - & - \\
\hline Bacteriastrum hyalinum & - & - & - & $160(1.4)$ & - & - \\
\hline Bacteriastrum varians & - & $1000(2.0)$ & - & - & - & - \\
\hline Biddulphia heteroceros & - & - & - & - & $160(0.8)$ & - \\
\hline Biddulphia mobiliensis & $400(1.0)$ & $1600(3.2)$ & - & - & $360(1.7)$ & - \\
\hline Biddulphia sinensis & $40(0.1)$ & - & - & - & - & - \\
\hline Biddulphia sp. & - & - & - & - & - & $440(0.8)$ \\
\hline Chaetoceros constrictus & - & $6200(12.4)$ & - & - & - & - \\
\hline
\end{tabular}


Chaetoceros curvisetus

Chaetoceros lorenzianus

Chaetoceros peruvianus

Chaetoceros socialis

Chaetoceros sp.

Chetoceros diversus

Cocconeis placentula

Corethron hystrix

Coscinodiscus eccentricus

Coscinodiscus eccentricus

Coscinodiscus gigas

Coscinodiscus sp.

Cyclotella striata

Cymbella sp.

Diploneis smithii

Diploneis weissflogii

Ditylum brightwellii

Ditylum sol

Eucampia sp.

Eucampia zoodiacus

Guinardia flaccida

Gyrosigma balticum

Leptocylindricus minimus

Leptocylindrus danicus

Licmophora sp.

Mediopyxis helysia

Melosira sp.

Melosira sulcata

Navicula heneiydii

Navicula sp.

Nitzschia longissima

Nitzscia sp.

Pleurosigma directum

Pleurosigma elongatum

Pleurosigma normanii

Pleurosigma sp.

Pseudonitzschia pungens

Pseudonitzschia sp.

Rhizosolenia crasispina

Rhizosolenia imbricata

Rhizosolenia setigera

Rhizosolenia stolterforthii

Rhizosolenia stylifromis

Skeletonema costatum

Surirella eximia

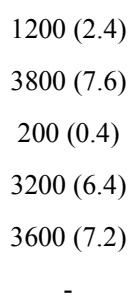

$40(0.1)$
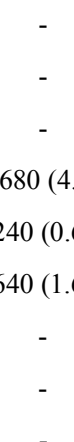

(1)

$160(0.4)$

$-$

640 (1.6)

$80(0.2)$
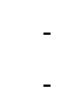

$200(0.4)$

$1000(2.0)$

$200(0.4)$

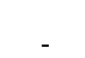

$2400(4.8)$

$\begin{array}{cc}- & 2400(4.8) \\ - & -\end{array}$

$160(0.4)$
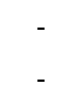

$40(0.1)$

$40(0.1)$

800 (1.6)

$400(0.8)$

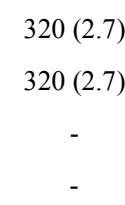

$1920(16.5)$

$44(1.8)$

$-\quad 160(1.4)$

509 (21.6)

$1440(12.4)$

98 (4.2)

$120(1.0)$

$1280(11.0)$
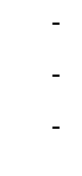

$160(1.4)$

320 (2.7)

$160(1.4)$
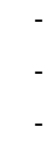

$120(1.0)$

$160(1.4)$

$320(2.7)$

$22(0.9)$
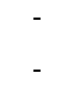

$11(0.5)$

-

$160(1.4)$

$1000(2.0)$

1600 (3.2)

$6600(13.3)$

160 (1.4)
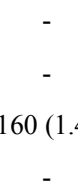

480 (4.1)
$40(0.2)$

$40(0.1)$
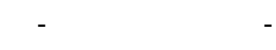

-

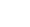

$1160(5.6)$

720 (1.4)

$120(0.2)$

$400(1.9)$
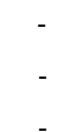

$40(0.2)$

$40(0.1)$

$80(0.4)$

$80(0.2)$

$120(0.6)$

$120(0.6)$

$80(0.2)$

$160(0.3)$

$120(0.6) \quad 80(0.2)$

$40(0.2)$

$240(1.2)$

$480(4.1)$ 
S. K. Baliarsingh et al.: Seasonal Variation of Phytoplankton Community in Navigable Channel of Gopalpur Port, East Coast of India: A Taxonomic Study

\begin{tabular}{|c|c|c|c|c|c|c|}
\hline Surirella fluminensis & - & - & - & - & $80(0.4)$ & - \\
\hline Surirella sp. & - & - & $284(12.0)$ & - & - & - \\
\hline Synedra sp. & - & - & $284(12.0)$ & - & - & - \\
\hline Tabellaria sp. & - & - & - & - & $120(0.6)$ & - \\
\hline Thalassionema nitzschioides & - & $2400(4.8)$ & - & - & - & - \\
\hline Thalassiosira hyalina & - & - & - & $160(1.4)$ & - & - \\
\hline Thalassiosira subtilis & - & - & - & $160(1.4)$ & - & - \\
\hline Thalassiothrix frauenfeldii & $80(0.2)$ & - & - & - & $280(1.4)$ & $240(0.5)$ \\
\hline Thalassiothrix longissima & $440(1.1)$ & $800(1.6)$ & $815(34.5)$ & $2080(17.9)$ & $300(1.4)$ & $40(0.1)$ \\
\hline Triceratium robertsianum & - & - & - & - & - & $40(0.1)$ \\
\hline Triceratium sp. & - & - & - & - & $40(0.2)$ & - \\
\hline \multicolumn{7}{|l|}{ DINOFLAGELLATE } \\
\hline Ceratium furca & $80(0.2)$ & - & - & - & - & - \\
\hline Ceratium trichoceros & - & - & - & - & $80(0.4)$ & - \\
\hline Ceratium tripos & - & - & - & - & $120(0.6)$ & - \\
\hline Dinophysis caudata & - & $200(0.4)$ & - & - & - & $40(0.1)$ \\
\hline Peridinium sp. & - & - & - & $120(1.0)$ & - & - \\
\hline Prorocentrum gracile & - & - & - & - & $80(0.4)$ & - \\
\hline Prorocentrum maxima & - & - & - & $320(2.7)$ & - & - \\
\hline Prorocentrum micans & $40(0.1)$ & $400(0.8)$ & - & $160(1.4)$ & - & - \\
\hline Protoperidinium depressum & - & - & - & - & $40(0.2)$ & - \\
\hline Protoperidinium sp. & - & $400(0.8)$ & - & - & - & - \\
\hline Pyrophacus steinii & $40(0.1)$ & - & - & - & - & - \\
\hline \multicolumn{7}{|l|}{ GREEN ALGAE } \\
\hline Botryococcus sp. & - & - & $33(1.4)$ & - & - & - \\
\hline Cosmarium sp. & - & - & $11(0.5)$ & - & - & - \\
\hline Eudorina elegans & - & - & $55(2.3)$ & - & - & - \\
\hline Pediastrum duplex & $1200(3.0)$ & - & - & - & - & - \\
\hline Pediastrum sp. & - & - & $22(0.9)$ & - & - & - \\
\hline Spondylosium sp. & - & - & $22(0.9)$ & - & - & - \\
\hline Staurastrum sp. & - & - & $65(2.8)$ & - & - & - \\
\hline Tetraedron sp. & - & - & $11(0.5)$ & - & - & - \\
\hline \multicolumn{7}{|l|}{ BLUE GREEN ALGAE } \\
\hline Anabaena sp. & - & - & $11(0.5)$ & - & - & - \\
\hline Oscillatoria sp. & - & $400(0.8)$ & - & - & - & - \\
\hline Phromidium sp. & - & - & $22(0.9)$ & - & - & - \\
\hline Spirulina sp. & - & - & $11(0.5)$ & - & - & - \\
\hline Total & 40360 & 49800 & 2360 & 11640 & 20700 & 53240 \\
\hline
\end{tabular}



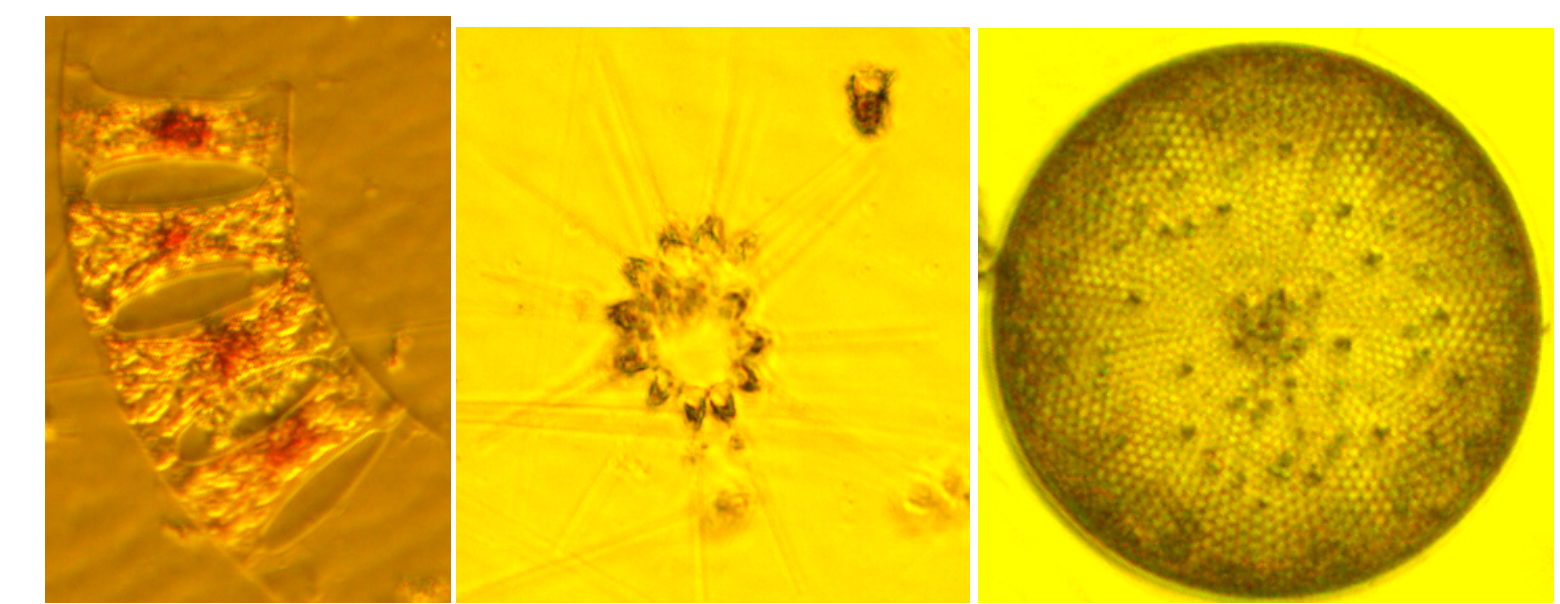

Eucampia sp (200X)

Asterionellopsis glacialis (400X)

Coscinodiscus sp.(100X)
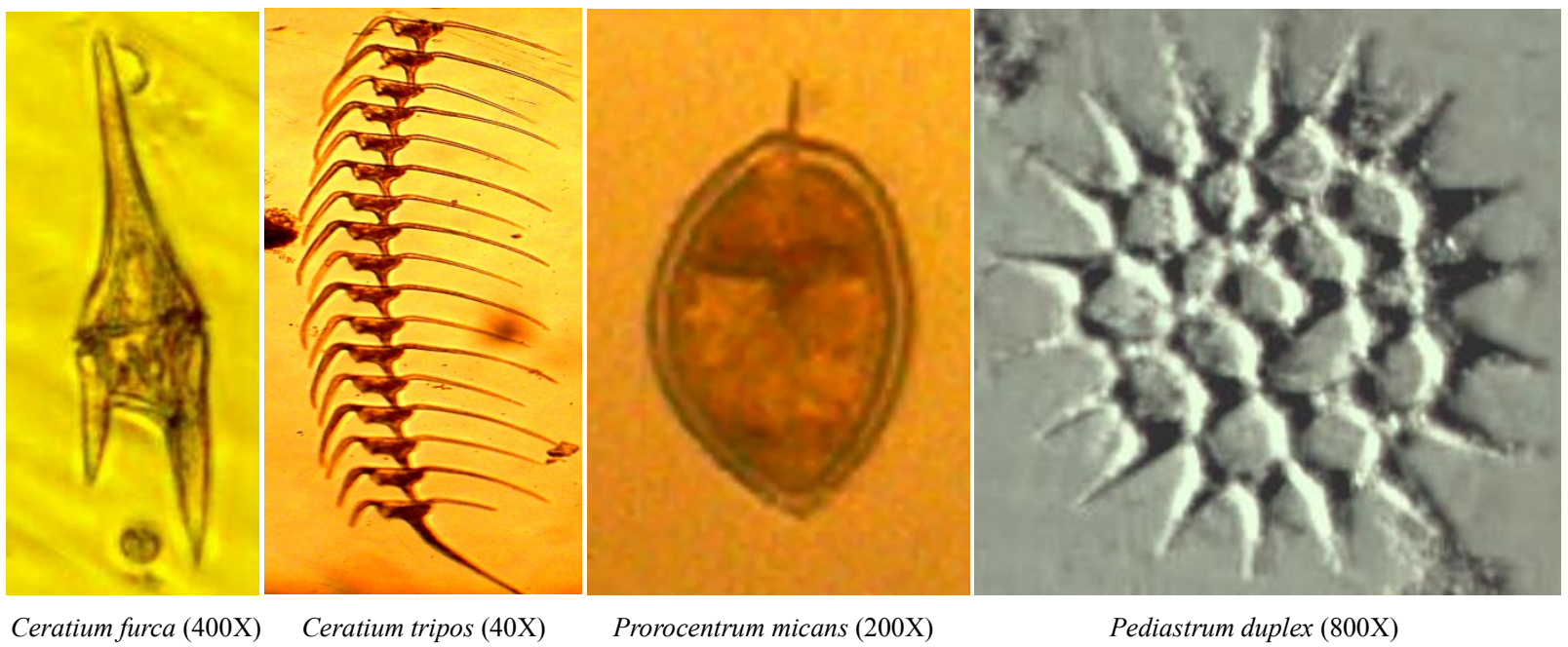

Prorocentrum micans (200X)

Pediastrum duplex (800X)

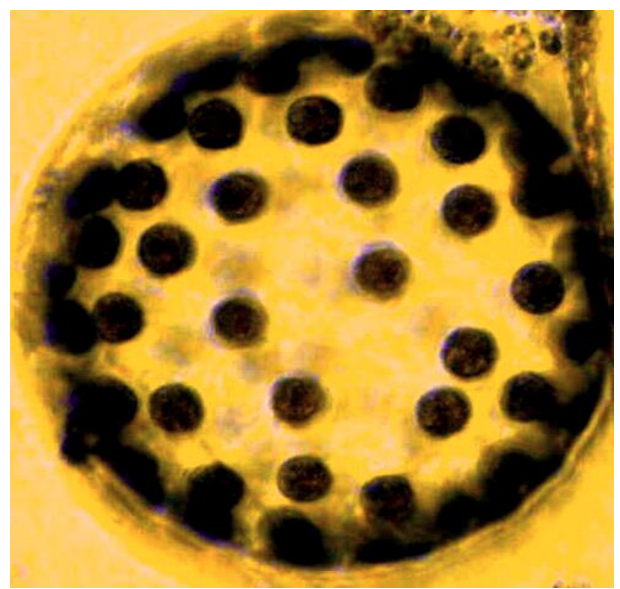

Eudorina elegans (600X)

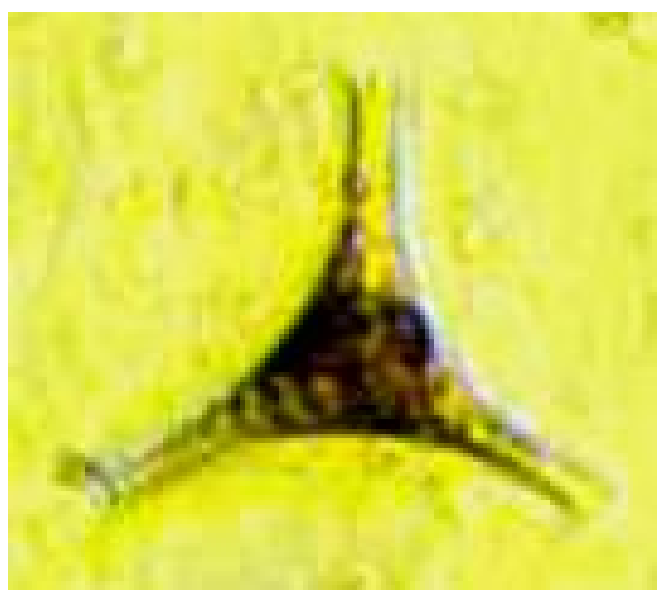

Staurastrum sp. $(800 \mathrm{X})$

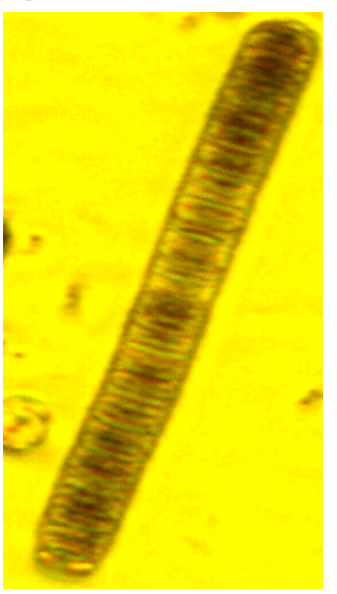

Oscillatoria sp.(100X)

Figure 2. Some important dominant phytoplankton species

As phytoplankton species composition determines the health of the food chain, our result depicts a healthy condition of the surrounding environment. Diatom dominance without any bloom can be treated as a major stable result for justifying the healthy condition. Presence of few toxic species is normal in occurrence in a port environment. The outcome of the present study will serve as baseline data to carry out future environmental impact assessment (EIA) studies for both existing port and another adjacent major all weather port under construction.

\section{ACKNOWLEDGEMENTS}

The present work was carried out as a part of INCOIS funded SATCORE project awarded to Berhampur University. All the authors are highly indebted to Dr. T.S 
Kumar and Dr. A. A Lotliker of INCOIS for their valuable suggestions during the course of study.

\section{REFERENCES}

[1] Waniek J. J., Holliday N. P., "Large - scale physical control on phytoplankton growth in the Irminger Sea, Part II: Model study of the physical and meteorological preconditioning", J Mar sys, 59, pp.219-237, 2006.

[2] Monbet Y., "Control of Phytoplankton Biomass in Estuaries: A Comparative Analysis of Microtidal and Macrotidal Estuaries", Estuaries, 15, pp.563-571, 1992.

[3] Cloern J. E., "The relative importance of light and nutrient limitation of phytoplankton growth: a simple index of coastal ecosystem sensitivity to nutrient enrichment", Aquatic Ecology, 33, pp.3-16, 1999

[4] Sin Y., Wetzel R. L., Anderson I. C., "Spatial and temporal characteristics of nutrient and phytoplankton dynamics in the York River Estuary, Virginia: analyses of long-term data" Estuaries, 22, pp.260-275, 1999.

[5] Gameiro C., Cartaxana P., Brotas V., "Environmental drivers of phytoplankton distribution and composition in Tagus Estuary, Portugal", Estuarine Coastal and Shelf Science, 75, pp.21-34, 2007.

[6] Bhaskar P. V., Roy R., Gauns M., Shenoy D. M., Rao V. D., Mochemadkar S., "Identification of non-indigenous phytoplankton species dominated bloom off Goa using inverted microscopy and pigment (HPLC) analysis", J Earth Syst Sci, pp.1145-1154, 2011.

[7] Cloern J. E., "Phytoplankton bloom dynamics in coastal ecosystems: A review with some general lessons from sustained investigation of San Fransisco Bay", California. Rev Geophys, 34(2), pp.127-168, 1996.

[8] Cupp E. E., Marine plankton diatoms of the West coast of North America, University of California Press, Berkeley, California, 1943.
[9] Newell G. E., Newell R. C., Marine Plankton- A Practical Guide, Hutchinson Educational Ltd, London, 1977.

[10] Verlencar X. N., Desai S., Phytoplankton Identification Manual, First Edition. National Institute of Oceanography, Dona Paula, Goa, India, 2004.

[11] Gharib S. M., El-Sherif Z. M., Abdel-Halim A. M., Radwan A. A., "Phytoplankton and environmental variables as a water quality indicator for the beaches at Matrouh, south-eastern Mediterranean Sea, Egypt: an assessment", Oceanologia, 53(3), pp.819-836, 2011.

[12] Paul J. T., Ramaiah N., Gauns M., Fernandes V., "Preponderance of a few diatom species among the highly diverse microphytoplankton assemblages in the Bay of Bengal”, Mar Biol, 152(1), pp.63-75, 2007.

[13] Panigrahy R. C., Gouda R., "Occurrence of the bloom of the Diatom Asterionella glacalis (Castracane) in the Rushikulya Estuary, East coast of India”, Mahasagar Bull. 23, pp.179-182, 1990.

[14] Mishra S., Sahu G., Mohanty A. K., Singh S. K., Panigrahy R. C., "Impact of the Diatom Asterionella glacialis (Castracane) Bloom on the Water Quality and Phytoplankton Community Structure in Coastal Waters of Gopalpur Sea, Bay of Bengal", Asian Journal of Water, Environment and Pollution, 3, pp.71-77, 2006.

[15] Naik S., Acharya B. C., Mohapatra A., "Seasonal variations of phytoplankton in Mahanadi estuary, east coast of India", Indian J Mar Sci, 38(2), pp.184-190, 2009.

[16] Rajasekar K. Thillai, Rajkumar M., Sun J. Ashok P. V., Perumal P., "Seasonal variations of phytoplankton diversity in the Coleroon coastal waters, southeast coast of India", Acta Oceanol Sin, 29, pp.97-108, 2010.

[17] Huang L. M., Chen Q. C., Wong C. K., "Distribution of Chlorophyll-a and its relation to environmental factors in the Zhujiang estuary", Collected Oceanic Works, 20, pp.39-46, 1997a.

[18] Huang L. M., Chen Q. C., Yin I. Q., Wen W. Y., He Y. Q., Wang H. X., "Basic organisim composition and environment status of Zhujiang estuary and adjacent waters", Mar Env Sci, 16 , pp.1-7, $1997 \mathrm{~b}$. 